\title{
BIBLIOMETRIC OVERVIEW OF OPERATIONS RESEARCH/ MANAGEMENT SCIENCE RESEARCH IN ASIA
}

\author{
PAO-LONG CHANG \\ School of Management Development \\ Feng Chia University, Taichung, Taiwan \\ plchang@fcu.edu.tw \\ PAO-NUAN HSIEH \\ Department of Library and Information Science \\ National Taiwan University, Taipei, Taiwan \\ pnhsieh@ntu.edu.tw
}

Received 25 October 2007

Accepted 6 January 2008

\begin{abstract}
This paper evaluates the distribution of papers published by Asian authors in Operations Research and Management Science (OR/MS) journals from 1968 to 2006. The impact of OR/MS research in Asia is compared with that of the United States and the World, and research trends are highlighted through an analysis of keywords. From 1968 to $2006,89,293$ papers were published in 60 OR/MS journals. Of these, $41.4 \%$ came from USA and $16.6 \%$ came from seven Asian countries/regions. The contribution of different countries/regions is as follows: Japan 3.7\%, Taiwan 3.2\%, India $2.3 \%$, Hong Kong $2.2 \%$, South Korea 2.1\%, People's Republic of China (PRC) 1.9\%, and Singapore 1.2\%. Among all the articles analyzed, $20 \%$ have a single author, and $9 \%$ have more than three authors; additionally, 22 papers have been cited more than 100 times and $29 \%$ have never been cited. Most articles originating in Japan, Taiwan, India, South Korea, PRC, and Singapore are produced in collaboration with local scholars, followed by authors from the United States. Hong Kong is a notable exception, 73\% of articles from Hong Kong are produced in cooperation with the PRC, followed by local scholars. The five most productive institutions are as follows: The Indian Institute of Technology, the Korea Advanced Institute of Science and Technology, the National University of Singapore, The Hong Kong Polytechnic University, and the National Chiao-Tung University (Taiwan).
\end{abstract}

Keywords: Operations research; management science; bibliometric analysis.

\section{Introduction}

Research in the fields of Operations Research and Management Science (OR/MS) has profoundly influenced the development of industry and the national economy. The survey conducted by Chen and Wei (2002) shows that OR/MS has been acknowledged by Taiwanese companies as an efficient managerial tool for economic 
development, with future usage likely to increase exponentially. Ranyard (1995) described the unique developmental path of OR in the UK, which originated with scientists assisting war-time operations, only to later transfer to industry in the immediate postwar years, where they have successfully solved the problems associated with most business functions.

Japan formed a unique refined industry based on learning about quality management after World War II, eventually prompting American researchers to consider why they could not match such achievements. Throughout the 1960s, and indeed up until the 1990s, Hong Kong, Singapore, South Korea, and Taiwan reached miraculous economic milestones by not only leading Asia in industrialization and technology, but also cultivating several unparalleled industries. Therefore, they are acclaimed as the Four Asian Tigers. These five economies share several common features. First, they are deeply nurtured by Chinese culture, where individuals are diligent and thrifty, with a concomitant emphasis on education that is conducive to economic development. Second, the complementary characteristic has to do with the widespread traumatic experience of war among the population, a phenomenon that has nurtured personal qualities of resilience and aggression, which have subsequently become harnessed to industrialization. Third, a factor is the political condition of relative stability, and in this context one might consider the formative influence of authoritarian politics in the initial phase of economic development. This legacy remains relevant in the sense that government policies are consistent and sustainable, with the attendant stability drawing foreign capital and technology as a stimulus to economic development. Fourth, the factor acknowledges how exogenous value systems can play a constructive role by connecting with the West technologically and institutionally. Fifth, a factor recognizes that these countries do not have vast lands and population, and are therefore export-oriented economies, in more endogenous terms. Contextualizing each of these constitutive elements makes an appreciable difference in situating present and future trends. This leads in turn to discussion of why the focus of attention at the turn of the 21st century is "Chindia", (i.e. China and India), both of which are assured of a promising future in terms of economic development. Given their abundant labor supply, they appear set to become the main manufacturing and service providers in the world. Indeed, these combined advantages will most likely transform "Chindia" into world economic superpowers in the near future.

Therefore, this study applies bibliometric analysis to analyze the international academic publications of OR/MS scholars in seven countries/regions in Asia, namely Hong Kong, India, Japan, People's Republic of China (PRC), Singapore, South Korea and Taiwan. Many OR/MS researchers from Asian countries/regions return to their home countries to teach or provide service after receiving doctoral education in the West. International publication has become an important indicator of academic performance, and so the researchers from these Asian countries/regions tend to share their research results with scholars in the same field through international publications. 
The value of publications is commonly rated by the rank of the journals in the Journal Citation Report (JCR) (Lenhard et al., 2006), which is published annually in two editions, science and social science, by The Thomson Corporation. JCR Science Edition includes data from over 5,900 journals in science and technology and ranks the journals by the impact factor (IF). The impact factor is a measure of the frequency with which the "average article" in a journal has been cited in a particular year or period. The annual JCR impact factor is a ratio of citations to recent citable items published. Thus, the impact factor of a journal is calculated by dividing the number of current year citations to the source items published in that journal during the previous two years (Garfield, 1994). Since this factor is an easily available means to quantify the value of scientific work, it is fast becoming widely adopted in the academic world.

The ISI Web of Science (WOS) includes information not only on the frequency of citations expressed by the IF, but also on the authors' origin, document type and the keywords of the individual articles. The present study uses this database further to explore these bibliometric indicators in order to measure the distribution of papers published by authors from these seven promising Asian countries/regions in OR/MS journals from 1968 to 2006.

\section{Method}

JCR Science Edition has Operations Research \& Management Science as a subject category. The 2006 edition has 60 journals (Appendix, listed alphabetically). This study searched the WOS database based on these 60 journals, and found that the WOS documents can be traced back to 1956 . The 60 journals in the OR/MS discipline published 89,293 papers from 1968 to 2006. Of these, American authors published 36,929 papers. In Asia, Japan is the country with both the earliest and the highest number of publications, with two appearing in 1968 (Miyasawa, 1968; Senju and Toyoda, 1968) and totaling 3,342. India also had a paper published in the same year (Erlenkotter and Manne, 1968). The first papers in Taiwan and Hong Kong both appeared in 1975. Taiwan has a total of 2,896 papers, second only to Japan in Asia, including three in 1975 (Chen and Hsiao, 1975; Shih and Chu, 1975; Wu and Shih, 1975). Hong Kong had two papers published in the same year (Chan, 1975a, 1975b). A Singaporean scholar published a book review in Interfaces in 1976 (Langham, 1976); South Korea had its first article published in 1978 (Lee, 1978), and the first article from a PRC scholar appeared in 1981 (Zheng, 1981). Therefore, the data collection criteria for publications stand as follows: at least one author had to be affiliated with one of the seven Asian countries/regions and the paper had to be published between 1968 and 2006 .

Many publications had multiple authors. We adopted an inclusive approach to counting, which was better able to evaluate author productivity. Each institution that appears in the author list receives one credit for an article. When articles are authored by collaborating institutions from multiple countries, each country receives 
one count for its participation, irrespective of the number of its collaborating institutions. For example, Taiwan and Singapore would each receive one credit for an article coauthored by one Taiwanese institution and two Singaporean institutions. Thus, the number of credits for an article is subject to variation, depending on the number of institutional authors and the number of countries represented among the collaborating institutions. When institutions collaborate, a single article is counted more than once.

The resident population (expressed in millions of inhabitants) was retrieved for each country from the CIA World Factbook.

\section{Results}

The 2006 edition of JCR OR/MS category includes 60 journals, of which 13 have an impact factor above 1 (2.516-1.036); Production and Operations Management and Journal of Operations Management have an impact factor above 2. If analyzed by region of publication, $35(58 \%)$ of the $60 \mathrm{OR} / \mathrm{MS}$ journals are from Europe; 22 $(37 \%)$ are from the United States and Canada. The seven Asian countries/regions have three journals (two from Singapore and one from Japan), thereby confirming that this discipline originated from Europe (Kirby, 2003). If simply analyzed by country, publication centers on America, the UK and the Netherlands. America has 21 journals, which is the largest number, followed by the UK with 17, the Netherland with 14, and Germany with three. Singapore publishes two titles, while Canada, France, Japan and Switzerland are responsible for one journal each.

Analysis conducted by subject category reveals that 16 of the $60 \mathrm{OR} / \mathrm{MS}$ journals, such as Management Science, Journal of Operations Management, and Operations Research, belong to the single discipline of OR/MS. Twenty-two journals belong simultaneously to two disciplines, and 21 journals belong to three disciplines. International Journal of Information Technology 8 Decision Making belongs to four subject categories. The discipline with most overlap is Industrial Engineering: 11 journals belong to OR/MS and Industrial Engineering at the same time; the one with the second most overlap is the discipline of Applied Mathematics, with ten journals crossing over into this discipline, and nine journals overlap with Manufacturing Engineering.

\subsection{Number of papers}

The number of academic papers published is an important indicator in scientific research. From 1968 to 2006, 14,816 papers were published by the seven Asian OR/MS researchers (Table 1). The leading countries were Japan (22.6\% of papers), Taiwan $(19.5 \%)$ and India (13.6\%). These figures can be usefully compared with the 36,929 papers published in the same period in the United States. Seven Asian countries/regions account for $16.6 \%$ of all OR/MS literature during the same period, in contrast to the $41.4 \%$ produced by the United States. In the first decade (19681976), the United States published 2,572 OR/MS papers which are 14 times as many 


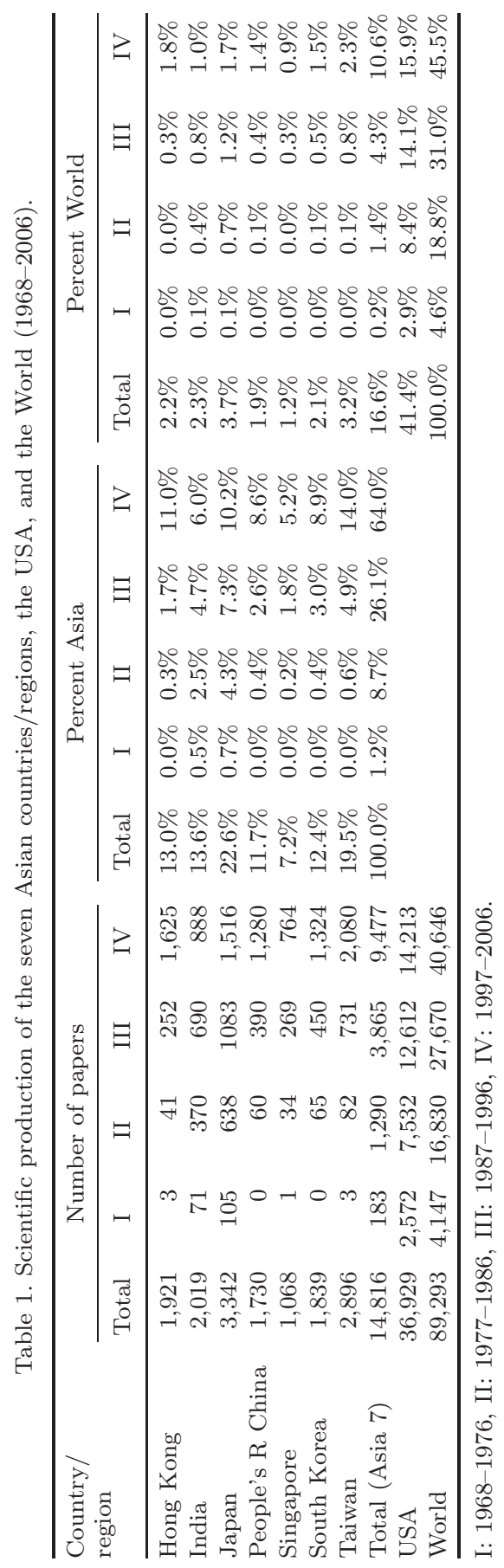


as that of the seven Asian countries/regions. However, this difference progressively reduced during the following decade to 1.5 times in the fourth decade (1997-2006). The number of OR/MS papers published in the different Asian countries/regions as compared to the total number of papers published in Asia changed slightly in the four decades examined, increasing in Taiwan, Hong Kong and Japan. Taiwan published $14 \%$ more papers in the fourth decade than in the first decade. Hong Kong's output increased by $11 \%$ during the same period, while Japan's increased by $10 \%$. The OR/MS output of all seven Asian countries/regions increased during the period examined.

Since the first OR/MS article appeared in Japan in 1968, its output has always been much higher than that from the other six Asian countries/regions (with the exception of 1975, when it was exceeded by India). The greatest number of papers from Japan was 199 in 1999, thereafter recording a sharp decline. For example, only 132 papers were published from Japan in 2006. The situation in India is similar to Japan. After the first OR/MS article appeared in 1968, its number of articles followed Japan closely, and has fluctuated since 1993. The number of articles exceeded 100 only in 1997, 2005 (103 papers) and 2006 (137 papers). Taiwan experienced the fastest growth in literature among the seven Asian countries/regions, having published three articles in 1975, and being second only to Japan in 1993. Taiwan eventually exceeded Japan in the year 2000, and then took the lead along the way. Taiwan produced 323 articles in 2005, making it the only Asian country with over 300 articles in a year. Another fast growing country is PRC. Since the first OR/MS article from PRC appeared in 1981, output has increased steadily over the years. It had over 100 articles in 1999, increasing to 250 in 2006. Exponential growth in Hong Kong became discernible from 1998.

The number of papers published in the international OR/MS journals by the scholars from the seven Asian countries/regions, show steady growth rates overall. Figure 1 indicates the largest number of papers came from Japan, with Taiwan and India following closely. The number of papers from Taiwan surpassed that from India, and followed that of Japan in 2000. The difference between the numbers of papers from Taiwan and Japan had become smaller in 2006. The number of papers, and the growth trend, in Hong Kong and South Korea are both very similar. PRC was late in starting to produce papers, but grew very fast, while Singapore has the smallest number of papers and the slowest growth pace.

The ratio of number of papers to country population in millions of inhabitants was 13.5 globally, 122.6 in the US, and 5.6 in the seven Asian countries/regions. In Asia, Hong Kong ranked first (275.2), followed by Singapore (234.7), Taiwan (126.7), South Korea (37.5), Japan (26.2), India (1.8), and PRC (1.3).

\subsection{Quality of papers}

International Journal of Systems Science published the most papers by researchers from the seven Asian countries/regions, ranked 53 by JCR 2006 OR/MS category 


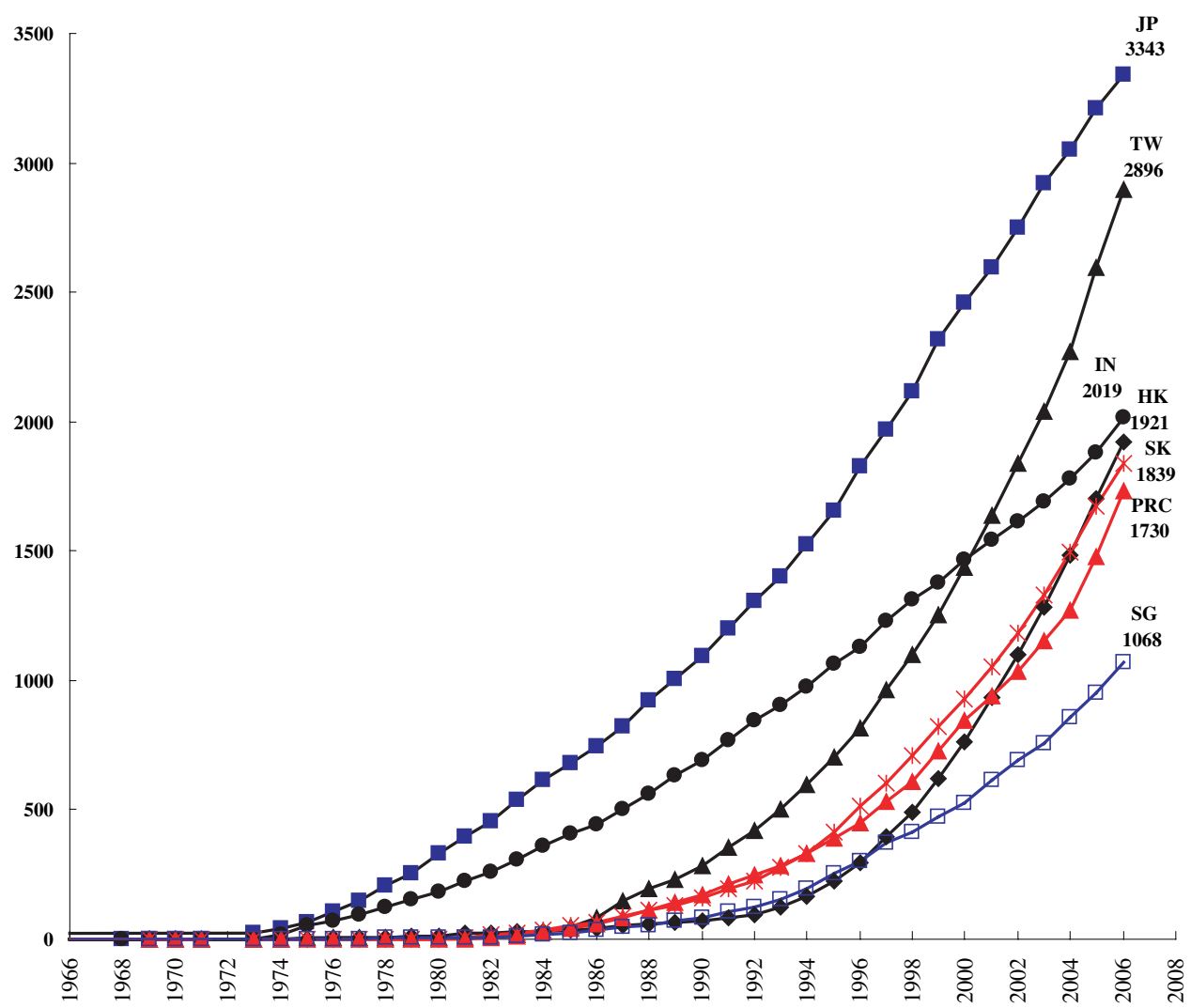

Fig. 1. Cumulated distribution of OR/MS papers in seven Asian countries/regions.

(1,779 papers, $12.41 \%$ ), followed by International Journal of Production Research, ranked $22(1,179,8.22 \%)$, and European Journal of Operational Research, ranked 16 $(1,158,9.55 \%)$. These three journals published over 1,000 papers by Asian scholars. Only one journal in OR/MS category, Military Operations Research, did not publish papers by scholars from the seven Asian countries/regions. Table 2 shows the ten most active journals, that is, those with the most papers published by researchers from the seven Asian countries/regions. This table presents the number of papers, percentage of total documents, the position of the journal in JCR OR/MS category, 2006 impact factor and the JCR category of journals. Only one journal listed in Table 2 has an IF value greater than 1, namely International Journal of Production Economics.

It is clear from Table 3 that Japan (2.1\%) ranks first, followed by Hong Kong $(1.67 \%)$ and Taiwan $(1.43 \%)$, in terms of the number of papers published in the top ten IF-ranked OR/MS journals. Among the seven Asian countries/regions, Singapore had the highest percentage of paper published in top ten journals, ranked 
Table 2. Ten most active journals containing most papers by the scholars from the seven Asian countries/regions (1968-2006).

\begin{tabular}{|c|c|c|c|c|c|c|c|}
\hline Rank & Journal & Papers & Percentage & $\begin{array}{l}2006 \\
\text { Rank }\end{array}$ & $\begin{array}{l}2006 \\
\text { IF }\end{array}$ & Country & $\begin{array}{l}\text { Subject } \\
\text { category }\end{array}$ \\
\hline 1 & $\begin{array}{l}\text { International Journal of } \\
\text { Systems Science }\end{array}$ & 1779 & 12.41 & 53 & 0.343 & GB & $\overline{\mathrm{OR} / \mathrm{MS}+2}$ \\
\hline 2 & $\begin{array}{l}\text { International Journal of } \\
\text { Production Research }\end{array}$ & 1179 & 8.22 & 22 & 0.799 & GB & $\mathrm{OR} / \mathrm{MS}+2$ \\
\hline 3 & $\begin{array}{l}\text { European Journal of } \\
\text { Operational Research }\end{array}$ & 1158 & 8.08 & 16 & 0.918 & NL & OR/MS \\
\hline 4 & $\begin{array}{l}\text { Journal of the Operations } \\
\text { Research Society of Japan }\end{array}$ & 833 & 5.81 & 55 & 0.292 & JP & OR/MS \\
\hline 5 & $\begin{array}{l}\text { Journal of Optimization } \\
\text { Theory and Applications }\end{array}$ & 709 & 4.95 & 31 & 0.633 & USA & $\mathrm{OR} / \mathrm{MS}+1$ \\
\hline 6 & $\begin{array}{l}\text { Expert Systems with } \\
\text { Applications }\end{array}$ & 547 & 3.82 & 14 & 0.957 & USA & $\mathrm{OR} / \mathrm{MS}+2$ \\
\hline 7 & $\begin{array}{l}\text { Computers } \& \text { Operations } \\
\text { Research }\end{array}$ & 529 & 3.69 & 17 & 0.893 & GB & $\mathrm{OR} / \mathrm{MS}+2$ \\
\hline 8 & $\begin{array}{l}\text { Reliability Engineering } 8 \\
\text { System Safety }\end{array}$ & 507 & 3.54 & 15 & 0.92 & GB & $\mathrm{OR} / \mathrm{MS}+1$ \\
\hline 9 & $\begin{array}{l}\text { Journal of the Operational } \\
\text { Research Society }\end{array}$ & 488 & 3.40 & 33 & 0.597 & GB & $\mathrm{OR} / \mathrm{MS}$ \\
\hline 10 & $\begin{array}{l}\text { International Journal of } \\
\text { Production Economics }\end{array}$ & 484 & 3.38 & 10 & 1.183 & NL & $\mathrm{OR} / \mathrm{MS}+2$ \\
\hline Total & & 8213 & 57.29 & 60 & & & \\
\hline
\end{tabular}

by JCR 2006 OR/MS category by IF, accounting for the total number of papers of that country, which was about $18 \%$. Singapore was followed by Hong Kong with 15.7\%, Japan with 11.4\%, PRC and South Korea were about 10\%, India with 9.2\%, and finally Taiwan with $8.9 \%$. (Table 3 ).

The top-tier journals known by OR/MS scholars are Management Science, Operations Research, INFORMS Journal on Computing, Production and Operations Management, and Journal of Operations Management. To investigate further the publication patterns of researchers from seven Asian countries/regions in the top-tier OR/MS journals, Singapore also had with the highest percentage of paper publication accounting for the total number of papers of that country, which was 6.5\% (69 papers), Hong Kong followed with 5\%, South Korea with $3.4 \%$, India with $2.7 \%$, Japan with $2.1 \%$, PRC with $1.4 \%$, and Taiwan with $1.1 \%$.

The percentage of papers published by scholars from the seven Asian countries/regions in the bottom ranked ten journals (JCR position 51-60) was the lowest in PRC at only $5.5 \%$ of the overall total of papers produced in OR/MS literature. It was followed by Taiwan with $6.3 \%$, Hong Kong with $6.5 \%$, Singapore and South Korea with $8.6 \%$, India with $11 \%$, and Japan with $27.7 \%$ (926 papers). The high percentage from Japan was because of the papers published in the 55th-ranked Journal of the Operations Research Society of Japan. 


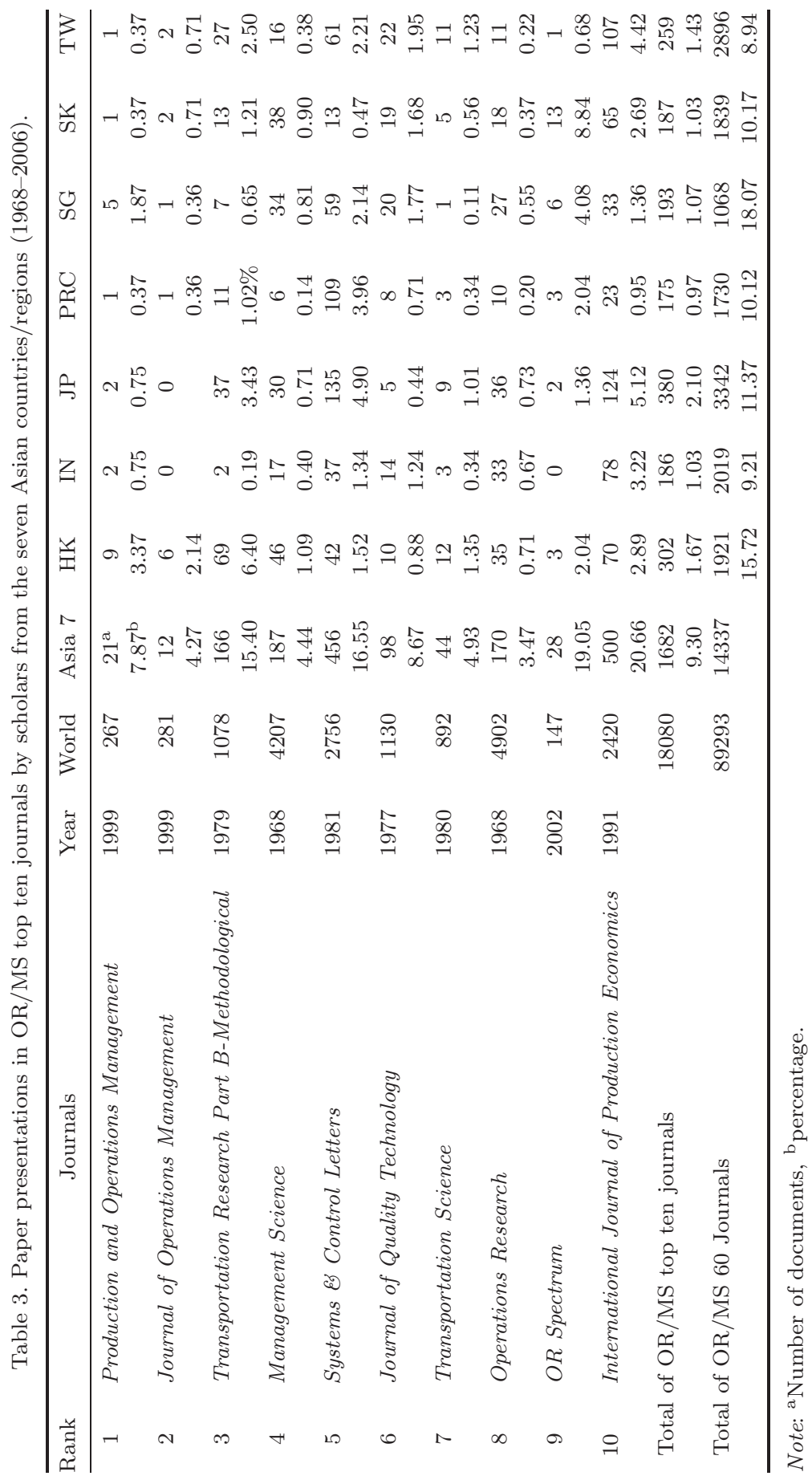




\subsection{Type of document}

The document types identified by the WOS database were analyzed. The most common was Journal Article, contributing about $96 \%$ of the total in Asia and $85 \%$

globally (Table 4). The second most common document type is Note, followed by Editorial material, Review, Book Review and Letter. Japan has the most types of document (12) in the seven Asian countries/regions, followed by Hong Kong and India, while PRC and Taiwan have the fewest. The document type with the largest number of documents is Note, with 59 and 42 published by Indian and Japanese scholars respectively. Hong Kong is the region with the most Review literature (18), followed by India (16) and Taiwan (12). Hong Kong also has the greatest number of Editorial materials, followed by Japan.

\subsection{Most productive institution}

The seven Asian countries/regions have 32 institutions, which published over 100 papers. The papers from India, Singapore, and South Korea tend to come from one single research institution. For instance, the institution with the most papers in Singapore is National University of Singapore (NUS) which produced 671 papers. Its closest competitor, Nanyang Technological University, was only able to match half this productive output (308), while Singapore Management University settled into third place with only 29 papers. Distinctive as these results may be, it is also instructive to consider the situation in India, not least because it is even more centralized than Singapore. The institution with the most papers is Indian Institute of Technology which has 704 papers, the largest number in Asia. The second place is Indian Institute of Management which has only 151 papers. The Indian Institutes of Technology (IITs) are a group of seven autonomous engineering and technology-oriented institutes of higher education established by the Government of India, but the statistical ramifications of this fact tend to be somewhat distorted by the methodology adopted by the Web of Science. The problems stem from how "INDIAN INST TECHNOL" is referenced as an institutional umbrella term to index the sum total of publications produced by the IITs. The most dispersed institutional distribution of papers can be found in PRC, where many institutions contend with one another. The institution with the highest tally is the Chinese Academy of Sciences which has 264 papers. Second place is occupied by Tsinghua University (161 papers). Shanghai Jiao Tong University comes in behind, with 82 papers. Table 5 presents the top twenty institutions.

Hong Kong and Taiwan each have five of the top 20 institutions with over 150 papers published. Japan has four, while India and Singapore have two respectively. PRC and South Korea each have one such institution. The distribution of research institutions in Hong Kong and Taiwan is more even. Hong Kong papers are mainly from five institutions: The Hong Kong Polytechnic University (472 papers), the Hong Kong University of Science and Technology (374 papers), the City University of Hong Kong (369 papers), the Chinese University of Hong Kong (357 papers) 


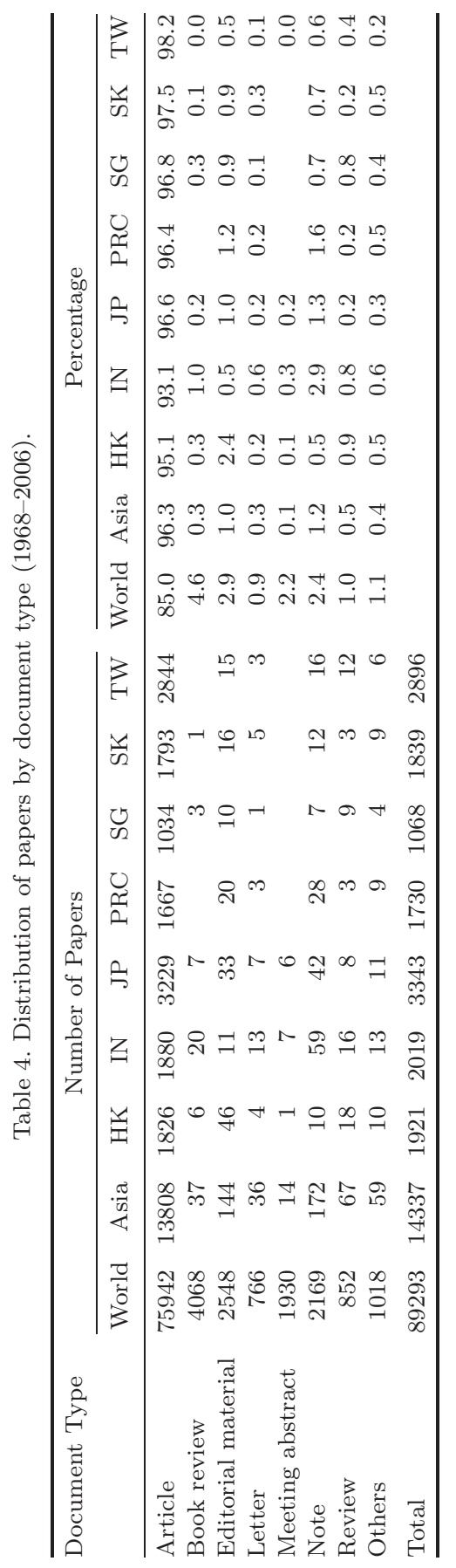


Table 5. Most productive institutions (1968-2006).

\begin{tabular}{clcc}
\hline Rank & \multicolumn{1}{c}{ Institutions } & Papers & Country \\
\hline 1 & Indian Inst Technol & 704 & IN \\
2 & Korea Adv Inst Sci \& Technol & 700 & SK \\
3 & Natl Univ Singapore & 671 & SG \\
4 & The Hong Kong Polytech Univ & 483 & HK \\
5 & Natl Chiao Tung Univ & 407 & TW \\
6 & City Univ Hong Kong & 382 & HK \\
7 & Hong Kong Univ Sci \& Technol & 378 & HK \\
8 & Kyoto Univ & 364 & HK \\
9 & Chinese Univ Hong Kong & 361 & JP \\
10 & Natl Cheng Kung Univ & 325 & TW \\
11 & Tokyo Inst Technol & 317 & JP \\
12 & Univ Hong Kong & 311 & HK \\
13 & Nanyang Technol Univ & 308 & SG \\
14 & Natl Tsing Hua Univ & 279 & TW \\
15 & Chinese Acad Sci & 264 & PRC \\
16 & Natl Taiwan Univ Sci \& Technol & 247 & TW \\
17 & Univ Tsukuba & 236 & JP \\
18 & Osaka Univ & 213 & JP \\
19 & Natl Taiwan Univ & 172 & TW \\
20 & Tsinghua Univ & 161 & PRC \\
\hline
\end{tabular}

and the University of Hong Kong (307 papers). The institutions with the greatest amount of literature in Taiwan are National Chiao-Tung University (ranking number 5), National Cheng Kung University, National Tsing-Hua University, National Taiwan University of Science and Technology, and National Taiwan University.

\subsection{Most productive authors}

Singapore is the country with the most authors of one paper only, accounting for $67 \%$ of the total, followed by Hong Kong and India (63\%), while Taiwan has the fewest $(58 \%)$. Taiwan has the greatest percentage of authors with over ten papers published (4\%), followed by $3.8 \%$ from Hong Kong and South Korea (Table 6).

The author with the most papers published in OR/MS journals in the seven Asian countries/regions is TCE Cheng from the Logistics Department of The Hong Kong Polytechnic University, having published a total of 133 papers. The author ranked second is Masao Fukushima from Kyoto University Graduate School Informatics (84 papers), XQ Yang from the Department of Applied Mathematics of The Hong Kong Polytechnic University attained third position (67 papers). Hirsch (2005) proposed the $h$-index, a new metric for characterizing the scientific output of a piece of research, which is defined as follows: "A scientist has index $h$ if $h$ of his or her $N p$ papers have at least $h$ citations each and the other $(N p-h)$ papers have $\leq h$ citations each", where $N p=$ total number of papers. Table 7 ranks the active Asian academics by the total items published and the total citations (times cited). Since some of the authors moved or returned to Asia after spending the earlier part of 


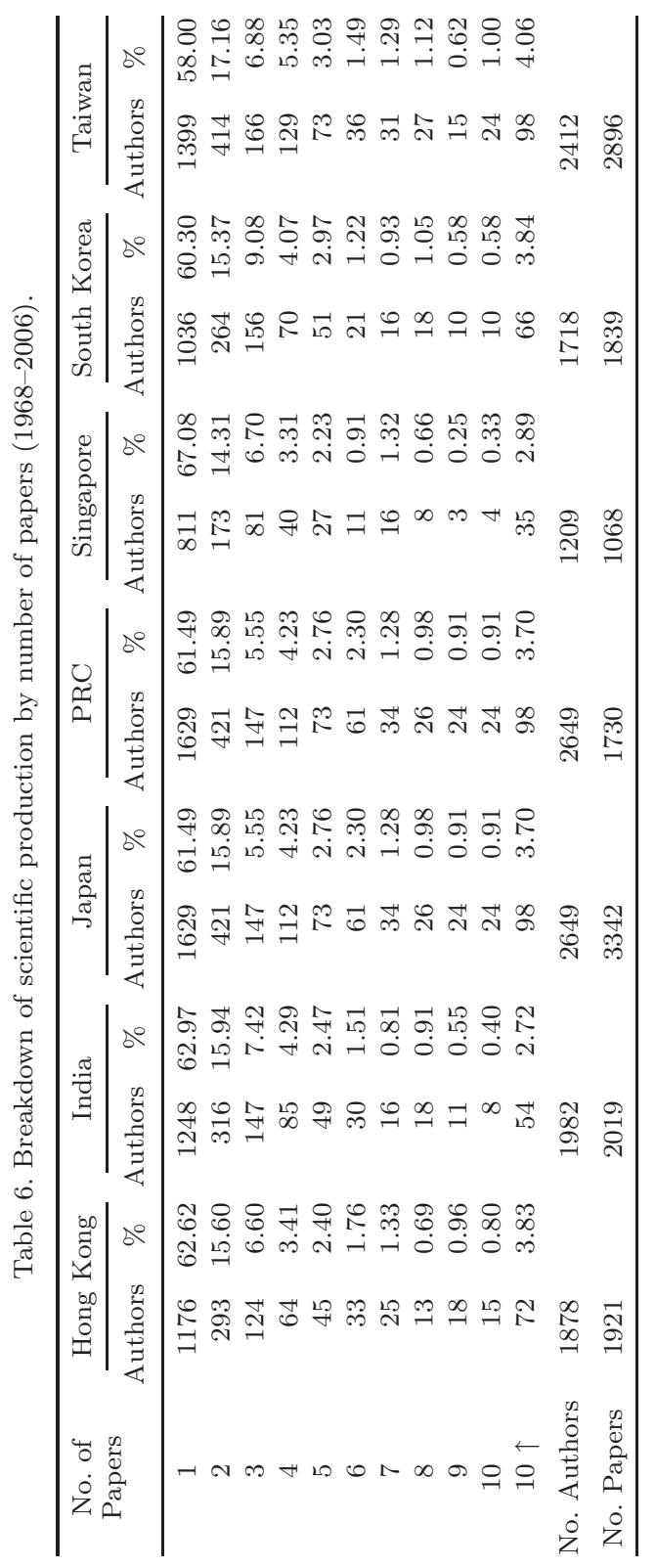




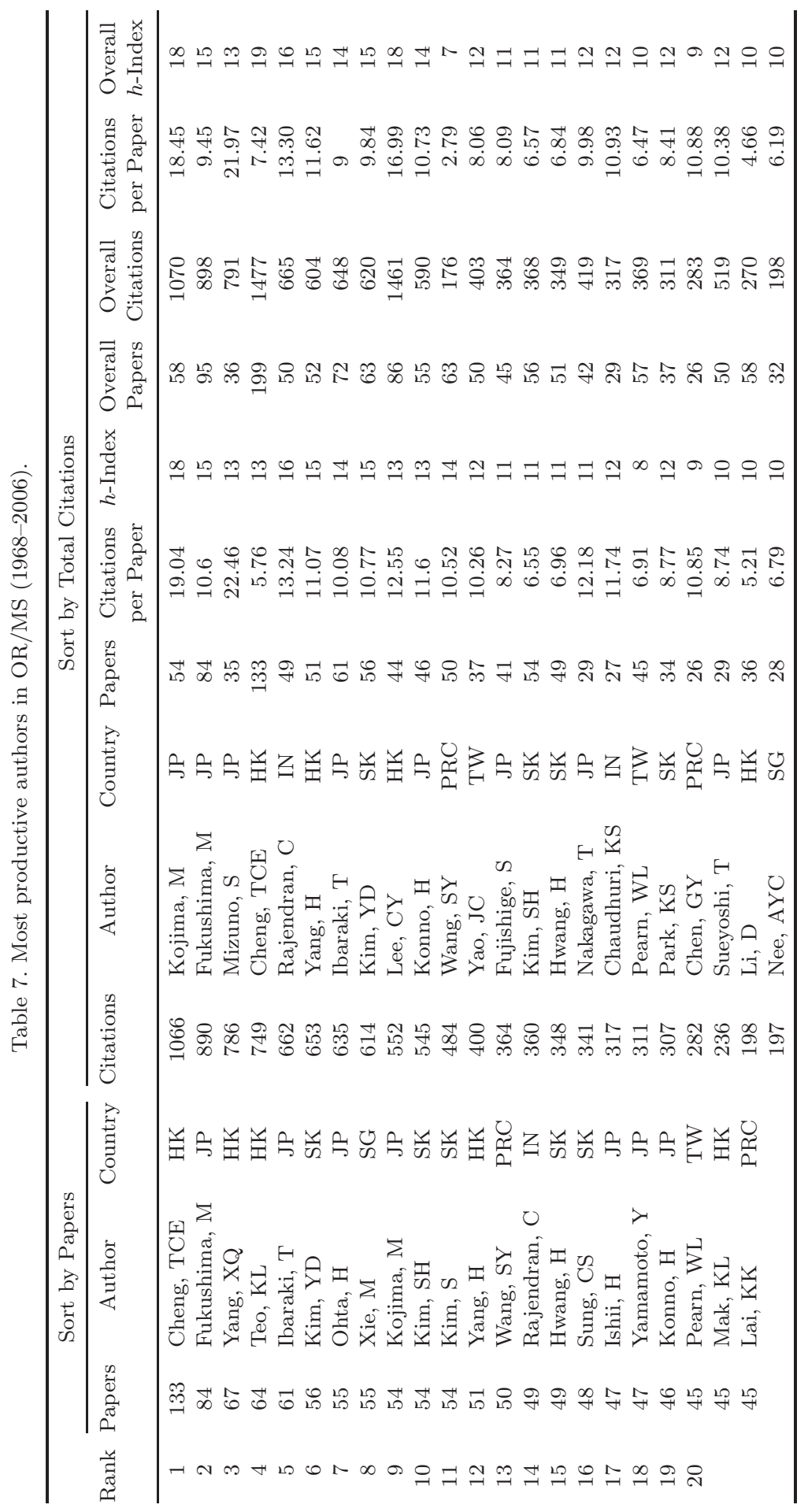


their academic and research careers in countries outside Asia, to give a fuller picture on the most active and influential OR/MS researchers from Asia, their overall number of publications, overall number of citations, and overall $h$-indices, regardless of their institutional affiliations, are presented as supplementary information in Table 7 .

\subsection{Co-author analysis}

Papers from Hong Kong have the greatest number of co-authors, with 4,936 authors for the 1,921 papers. That is, Hong Kong has 2.57 authors per paper on average. The next largest number of co-authors is from Singapore, with 2,644 authors for 1,068 papers (i.e. 2.48 authors per paper on average). The smallest number of coauthors is in Japan, with 3,343 papers contributed by 7,112 authors, amounting to 2.13 authors per paper on average. The 2,896 papers published in Taiwan are the contributions of 6,376 authors, which equates to 2.2 authors per paper on average. Overall, the most common collaboration is between two authors publishing OR/MS papers in the seven Asian countries/regions. India accounts for $52 \%$, followed by Taiwan and South Korea 47\%. The second common cooperation is among three authors, of which Singapore accounts for about 35\%, followed by Hong Kong with $34 \%$.

The country with the most single-author papers is Japan, approximately $31 \%$ of papers. PRC is the next with about $21 \%$. South Korea has the fewest single authors, with slightly less than $11 \%$, while Hong Kong only accounts for about $12 \%$.

The largest number of co-authors for a paper is 16, originated from PRC. It was co-written by five American authors and 11 PRC authors (Kuby et al., 1995). One paper in Japan has ten authors, and four papers with nine authors. Of the latter group, two are from Japan, and one each is from Singapore and Taiwan. The greatest number of authors for a single paper in Taiwan is nine, which included seven American authors, in addition to another two from Japan and Taiwan (Adams et al., 1996).

On the whole, it is clear that most papers published in the OR/MS journals generally involve only one to three authors. Of such papers, India accounts for nearly 95\%; Taiwan (93\%); Japan (92\%); PRC and South Korea (each 89\%); Singapore 87\%; Hong Kong (slightly less than 85\%). Table 8 provides a more complete analysis.

The number of authors collaborating with researchers from different countries serves as a significant indicator of the globalization of that discipline. Table 9 indicates that the scholars from India, Japan, PRC, Singapore, South Korea and Taiwan, prefer to work with domestic scholars, and the percentage can reach $100 \%$. Other than domestic scholars, the six countries exhibit a marked preference for scholars from the United States. South Korea has the highest percentage in terms of co-authorship, where $21 \%$ of papers were produced in cooperation with American scholars, followed by Hong Kong, PRC, Singapore and Taiwan. The country with 
Table 8. Breakdown of scientific production by number of authors (1968-2006).

\begin{tabular}{cccccccc}
\hline No. of Authors & HK & IN & JP & PRC & SG & SK & TW \\
\hline 1 & 223 & 364 & 1,040 & 370 & 191 & 199 & 602 \\
& $11.61 \%$ & $18.03 \%$ & $31.11 \%$ & $21.39 \%$ & $17.88 \%$ & $10.82 \%$ & $20.79 \%$ \\
2 & 746 & 1045 & 1,217 & 678 & 366 & 869 & 1,366 \\
& $38.83 \%$ & $51.76 \%$ & $36.40 \%$ & $39.19 \%$ & $34.27 \%$ & $47.25 \%$ & $47.17 \%$ \\
3 & 658 & 503 & 821 & 478 & 370 & 572 & 726 \\
& $34.25 \%$ & $24.91 \%$ & $24.56 \%$ & $27.63 \%$ & $34.64 \%$ & $31.10 \%$ & $25.07 \%$ \\
4 & 239 & 87 & 199 & 161 & 108 & 148 & 162 \\
& $12.44 \%$ & $4.31 \%$ & $5.95 \%$ & $9.31 \%$ & $10.11 \%$ & $8.05 \%$ & $5.59 \%$ \\
5 & 43 & 16 & 41 & 34 & 25 & 39 & 30 \\
6 or more & $2.24 \%$ & $0.79 \%$ & $1.23 \%$ & $1.97 \%$ & $2.33 \%$ & $2.12 \%$ & $1.04 \%$ \\
& 12 & 4 & 25 & 9 & 8 & 12 & 10 \\
Total & $0.63 \%$ & $0.20 \%$ & $0.75 \%$ & $0.52 \%$ & $0.75 \%$ & $0.65 \%$ & $0.35 \%$ \\
No. Papers & 4936 & 4416 & 7112 & 4041 & 2644 & 4514 & 6376 \\
Average & 1921 & 2,019 & 3,343 & 1730 & 1,068 & 1,839 & 2,896 \\
\hline
\end{tabular}

the second largest degree of cooperation varies by country: India, PRC and South Korea scholars are content to work with Canadian scholars

More than $70 \%$ of Hong Kong scholars work with PRC scholars to publish their papers, with fellow Hong Kong scholars serving as a secondary reserve of intellectual capital. Additionally, Hong Kong scholars network with scholars from Canada, the United Kingdom, Singapore, Australia and Taiwan. Overall, international cooperation is the most active in Hong Kong and then Singapore.

Which scholars typically publish papers together is another important issue. Of the seven Asian countries/regions studied, PRC has the highest percentage of single papers authored by different pairs of collaboration (87\%), followed by South Korea and Taiwan (each approximately 80\%). Hong Kong has the lowest percentage, $70 \%$. The greatest number of collaborating pairs of authors producing over ten papers is seven from Japan, followed by five from Hong Kong, two from Singapore, and one each from India and Taiwan.

Table 10 indicates that OR/MS research in PRC is diversified and contentious, inasmuch as a clear research network currently remains at an emergent developmental stage. India has the greatest number of co-author papers among the seven Asian countries/regions. The collaboration network between India and PRC can accordingly undergo further comparison through network analysis. Figure 2 demonstrates that Indian authors who co-publish over three papers have very strong networks, and are likewise inclined to write and publish more papers together (the thickness of lines represents the number of papers, thus highlighting the network ties). In contrast, the collaborative networks among PRC authors are more dispersed in the absence of a clear research network, leading to fewer jointly authored papers being published. 


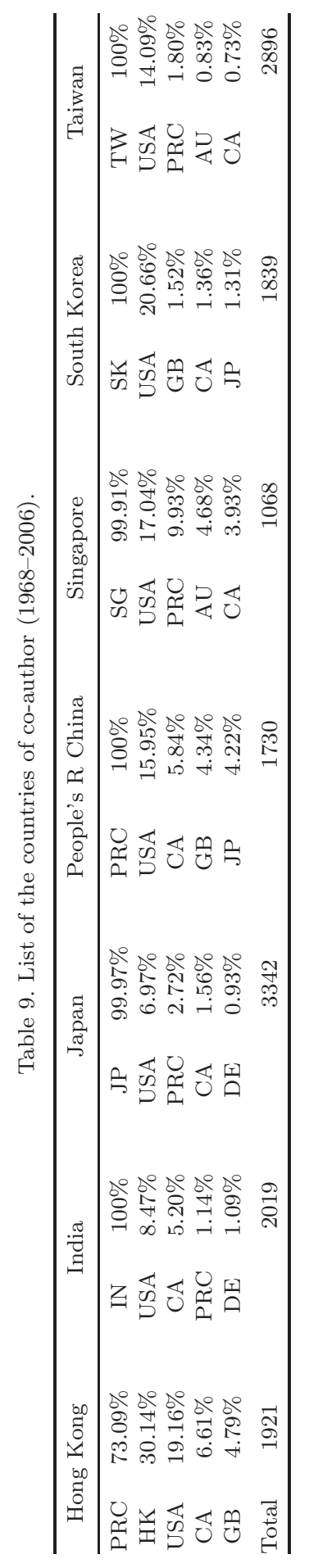


Table 10. Number of papers published by collaboration pairs in seven Asian countries/regions (1968-2006).

\begin{tabular}{cccccccc}
\hline \multirow{2}{*}{$\begin{array}{c}\text { No. of } \\
\text { Papers }\end{array}$} & HK & IN & \multicolumn{5}{c}{ No. of Pairs } \\
\cline { 3 - 8 } & & & JP & PRC & SG & SK & TW \\
\hline 1 & 532 & 372 & 468 & 491 & 426 & 666 & 482 \\
& $69.63 \%$ & $78.81 \%$ & $77.74 \%$ & $87.06 \%$ & $75.94 \%$ & $80.73 \%$ & $79.02 \%$ \\
2 & 123 & 62 & 77 & 53 & 94 & 112 & 76 \\
& $16.10 \%$ & $13.14 \%$ & $12.79 \%$ & $9.40 \%$ & $16.76 \%$ & $13.58 \%$ & $12.46 \%$ \\
3 & 51 & 14 & 23 & 6 & 22 & 27 & 33 \\
& $6.68 \%$ & $2.97 \%$ & $3.82 \%$ & $1.06 \%$ & $3.92 \%$ & $3.27 \%$ & $5.41 \%$ \\
4 & 16 & 10 & 10 & 10 & 8 & 12 & 10 \\
& $2.09 \%$ & $2.12 \%$ & $1.66 \$$ & $1.77 \%$ & $1.43 \%$ & $1.45 \%$ & $1.64 \%$ \\
5 & 15 & 6 & 5 & 1 & 6 & 7 & 3 \\
& $1.96 \%$ & $1.27 \%$ & $0.83 \%$ & $0.18 \%$ & $1.07 \%$ & $0.85 \%$ & 0.49 \\
$6 \uparrow$ & 27 & 8 & 19 & 3 & 5 & 1 & 6 \\
& $3.53 \%$ & $1.69 \%$ & $3.16 \%$ & $0.53 \%$ & $0.89 \%$ & $0.12 \%$ & $0.98 \%$ \\
Unique Pairs & 764 & 472 & 602 & 564 & 561 & 825 & 610 \\
\hline
\end{tabular}

\subsection{Most cited authors}

Nineteen papers published by authors from the seven Asian countries/regions are cited over 100 times. These comprise seven from Japan, which is the largest number, four from India, three from Taiwan, two from PRC and Singapore respectively, and one from Hong Kong. The most cited paper from South Korea has only been cited 89 times.

The most cited paper is the collaboration between E Pardoux from Shandong University and SG Peng from Fudan University, which has been cited 226 times. The second most cited paper is co-written by KY Tam from the Hong Kong University of Science and Technology and MY Kiang from Arizona State University (cited 189 times). The paper co-produced by SS Keerthi from the Indian Institute of Science, and EG Gilbert from Aerospace Engineering Department of Michigan University in America, has been cited 175 times, earning it a respectable third place in the collaborative citation ranking (Table 11).

\subsection{Research topics analysis}

This paper analyzes the keywords listed by the author to analyze differences among the research interests of OR/MS scholars in the seven Asian countries/regions. Each author might choose different types of words when listing key words. Most scholars use plural forms such as "fuzzy sets" and "fuzzy sets theory", while few settle for singular forms, such as "fuzzy set", "fuzzy set theory". Some employ full names, such as "data envelopment analysis", while others resort to its acronym "DEA", with both acronym and full name, as "DEA (data envelopment analysis)" or "data envelopment analysis (DEA)", making recurrent appearances in the literature as well. Naturally differences also occur in spelling, i.e. "data envelop analysis" is also 


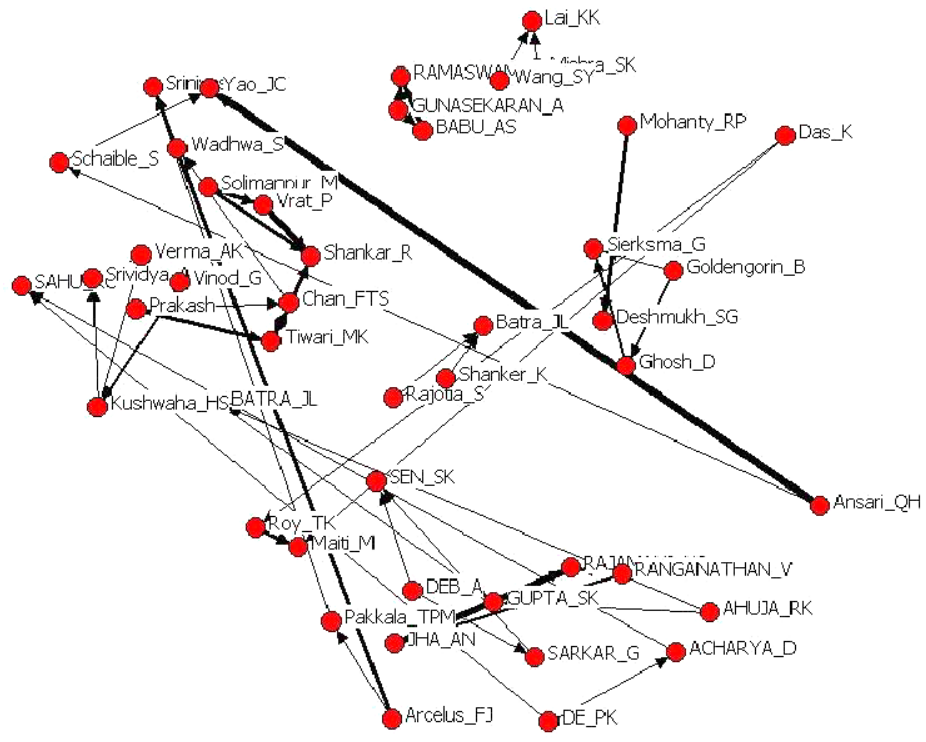

\section{Indian}

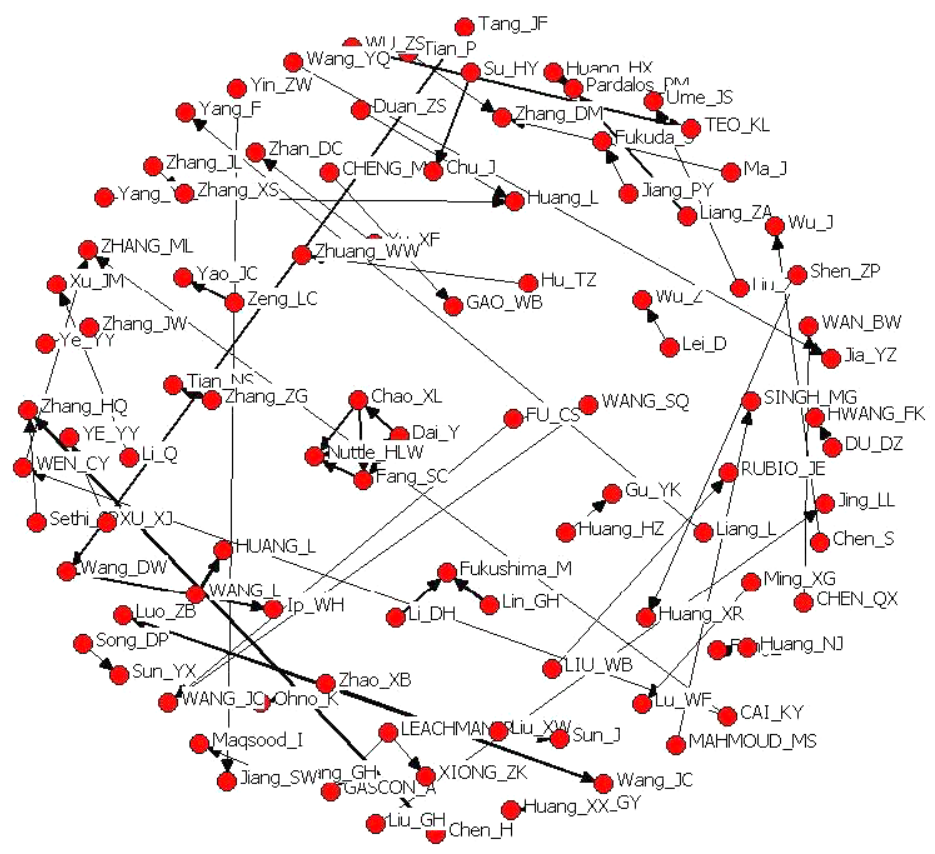

\section{People's R China}

Fig. 2. Author collaboration networks of India and People's R China. 
Table 11. The most cited papers (1968-2006).

\begin{tabular}{ccccc}
\hline Rank & Time Cited & Self-Cited & Country & \\
\hline 1 & 226 & 28 & PRC & (Pardoux and Peng, 1990) \\
2 & 189 & 3 & HK & (Tam and Kiang, 1992) \\
3 & 175 & 2 & IN & (Keerthi and Gilbert, 1988) \\
4 & 171 & 12 & JP & (Fukushima, 1992) \\
5 & 162 & 33 & JP & (Koarn, Kotz, and Johnson, 1992) \\
6 & 160 & 57 & TW & (Sugimori, Kusunoki, Cho, and Uchikawa, 1977) \\
7 & 157 & 0 & IN & (Chandrasekharan and Rajagopalan, 1987) \\
8 & 155 & 0 & JP & (Chen, Drezner, Ryan and Simchi-Levi, 2000) \\
9 & 154 & 2 & JP & (Furuta, 1990) \\
10 & 148 & 12 & IN &
\end{tabular}

Table 12. Top 20 keywords (1968-2006).

\begin{tabular}{clc}
\hline Rank & \multicolumn{1}{c}{ Keywords } & Frequency \\
\hline 1 & inventory & 329 \\
2 & scheduling & 290 \\
3 & genetic algorithm & 242 \\
4 & heuristics & 233 \\
5 & optimization & 220 \\
6 & dynamic programming & 158 \\
7 & simulation & 145 \\
8 & neural networks & 138 \\
9 & data envelopment analysis & 137 \\
10 & linear programming & 126 \\
11 & supply chain management & 125 \\
12 & reliability & 120 \\
13 & global optimization & 118 \\
14 & branch and bound & 99 \\
15 & global convergence & 99 \\
16 & integer programming & 97 \\
17 & data mining & 93 \\
18 & analytic hierarchy process & 87 \\
19 & fuzzy sets & 83 \\
20 & simulated annealing & 82 \\
\hline
\end{tabular}

used. Hence it is prudent to make allowance for different types of keywords when analyzing them.

Table 12 lists the top 20 keywords used by OR/MS scholars in the seven Asian countries/regions. The most widely studied research topics in the seven Asian countries/regions include inventory, scheduling, genetic algorithm, heuristics and optimization. The research topics unique to Taiwanese scholars are fuzzy sets, data mining, reliability, and data envelopment analysis. Further analysis of the keywords among papers from Taiwan, Hong Kong, and PRC reveals that the research topics of PRC scholars are the most dispersed, and the key words are the most definite. The research interests of Taiwan and Hong Kong scholars are similar. The most popular research topic in Taiwan is inventory, which ranks number five in Hong Kong. However, only 12 PRC papers use a keyword relating to this topic. Taiwan 
and Hong Kong have the most papers discussing dynamic planning, while PRC has the most papers on linear programming.

\section{Conclusion}

This paper considers only journals quoted by ISI as OR/MS journals. The analytical approach employed herein has some limitations, and does not cover all the OR/MS publications from 1968 to 2006. Indeed, OR/MS scholars do not necessarily publish their papers in OR/MS journals, but can submit their results to journals of other fields that specifically address their areas of interest. The process of identifying OR/MS papers in other journals is complicated and too impractical to be broached in this study. New methods are worth developing that could perform a series of related functions. Particularly noteworthy in this regard is the identification of an author's scientific background, in tandem with the matching of keywords, names of the authors and Institutions of provenance, all of which will greatly enrich future understanding of the scientific performance of OR/MS scholars in Asia.

In conclusion, the present study offers a fairly complete and reliable overview of OR/MS research in Asian in the years between 1968 and 2006. In the seven Asian countries/regions under review here, the OR/MS research is active and productive, and accounts for $16.6 \%$ of all the OR/MS fields. In a highly competitive world, to precisely know its position in comparison with its competitors can be utilized to identify the strategies to improve the property of allocation of resources and therefore to upgrade the quality of its research.

Appendix. 60 Journals listed under the subject category of OR/MS in JCR 2006 version.

\begin{tabular}{|c|c|c|c|c|c|c|}
\hline Journal Title & $\begin{array}{l}\text { Rank } \\
\text { by IF }\end{array}$ & $\begin{array}{l}\text { Impact } \\
\text { Factor }\end{array}$ & Articles & $\begin{array}{l}\text { Issues/ } \\
\text { Year }\end{array}$ & $\begin{array}{l}\text { Country/ } \\
\text { Territory }\end{array}$ & $\begin{array}{l}\text { Subject } \\
\text { categories }\end{array}$ \\
\hline $\begin{array}{l}\text { Annals of Operations } \\
\quad \text { Research }\end{array}$ & 34 & 0.589 & 129 & 8 & Netherlands & 1 \\
\hline $\begin{array}{l}\text { Applied Stochastic Models } \\
\text { in Business and } \\
\text { Industry }\end{array}$ & 47 & 0.443 & 40 & 4 & England & 3 \\
\hline $\begin{array}{l}\text { Asia-Pacific Journal of } \\
\text { Operational Research }\end{array}$ & 51 & 0.375 & 31 & 4 & Singapore & 1 \\
\hline $\begin{array}{l}\text { Computers \& Operations } \\
\text { Research }\end{array}$ & 17 & 0.893 & 183 & 14 & England & 3 \\
\hline $\begin{array}{l}\text { Computational } \\
\text { Optimization and } \\
\text { Applications }\end{array}$ & 21 & 0.8 & 51 & 9 & United States & 2 \\
\hline $\begin{array}{l}\text { Concurrent } \\
\text { Engineering-Research } \\
\text { and Applications }\end{array}$ & 36 & 0.569 & 29 & 4 & England & 3 \\
\hline Decision Support Systems & 11 & 1.16 & 156 & 11 & Netherlands & 3 \\
\hline $\begin{array}{l}\text { Discrete Event Dynamic } \\
\text { Systems-Theory and } \\
\text { Applications }\end{array}$ & 13 & 1.036 & 19 & 4 & United States & 3 \\
\hline
\end{tabular}


Appendix. (Continued)

\begin{tabular}{|c|c|c|c|c|c|c|}
\hline Journal Title & $\begin{array}{l}\text { Rank } \\
\text { by IF }\end{array}$ & $\begin{array}{l}\text { Impact } \\
\text { Factor }\end{array}$ & Articles & $\begin{array}{l}\text { Issues/ } \\
\text { Year }\end{array}$ & $\begin{array}{l}\text { Country/ } \\
\text { Territory }\end{array}$ & $\begin{array}{l}\text { Subject } \\
\text { categories }\end{array}$ \\
\hline Engineering Optimization & 39 & 0.557 & 57 & 6 & England & 2 \\
\hline $\begin{array}{l}\text { European Journal of } \\
\quad \text { Operational Research }\end{array}$ & 16 & 0.918 & 651 & 24 & Netherlands & 1 \\
\hline $\begin{array}{l}\text { Expert Systems with } \\
\quad \text { Applications }\end{array}$ & 14 & 0.957 & 162 & 8 & United States & 3 \\
\hline IIE Transactions & 30 & 0.637 & 86 & 12 & United States & 2 \\
\hline INFOR & 59 & 0.095 & 10 & 4 & Canada & 2 \\
\hline $\begin{array}{l}\text { Informs Journal on } \\
\text { Computing }\end{array}$ & 18 & 0.865 & 40 & 4 & United States & 2 \\
\hline $\begin{array}{l}\text { International Journal of } \\
\text { Computer Integrated } \\
\text { Manufacturing }\end{array}$ & 50 & 0.383 & 69 & 6 & England & 3 \\
\hline $\begin{array}{l}\text { International Journal of } \\
\text { Flexible Manufacturing } \\
\text { Systems }\end{array}$ & 46 & 0.448 & 3 & 4 & United States & 2 \\
\hline $\begin{array}{l}\text { International Journal of } \\
\text { Information Technology } \\
\& \mathcal{G} \text { Decision Making }\end{array}$ & 19 & 0.818 & 46 & 4 & Singapore & 4 \\
\hline $\begin{array}{l}\text { International Journal of } \\
\quad \text { Production Economics }\end{array}$ & 10 & 1.183 & 217 & 18 & Netherlands & 3 \\
\hline $\begin{array}{l}\text { International Journal of } \\
\quad \text { Production Research }\end{array}$ & 22 & 0.799 & 270 & 18 & England & 3 \\
\hline $\begin{array}{l}\text { International Journal of } \\
\text { Systems Science }\end{array}$ & 53 & 0.343 & 98 & 12 & England & 3 \\
\hline $\begin{array}{l}\text { International Journal of } \\
\text { Technology } \\
\text { Management }\end{array}$ & 57 & 0.233 & 84 & 8 & Switzerland & 2 \\
\hline Interfaces & 54 & 0.338 & 44 & 6 & United States & 1 \\
\hline $\begin{array}{l}\text { Journal of Global } \\
\text { Optimization }\end{array}$ & 37 & 0.568 & 100 & 8 & Netherlands & 2 \\
\hline $\begin{array}{l}\text { Journal of Industrial and } \\
\text { Management } \\
\text { Optimization }\end{array}$ & 42 & 0.488 & 21 & 4 & United States & 3 \\
\hline $\begin{array}{l}\text { Journal of Manufacturing } \\
\text { Systems }\end{array}$ & 58 & 0.15 & & 6 & United States & 3 \\
\hline $\begin{array}{l}\text { Journal of Operations } \\
\text { Management }\end{array}$ & 2 & 2.042 & 49 & 6 & Netherlands & 1 \\
\hline $\begin{array}{l}\text { Journal of the Operational } \\
\quad \text { Research Society }\end{array}$ & 33 & 0.597 & 139 & 12 & England & 1 \\
\hline $\begin{array}{l}\text { Journal of the Operations } \\
\text { Research Society of } \\
\text { Japan }\end{array}$ & 55 & 0.292 & 17 & 4 & Japan & 1 \\
\hline $\begin{array}{l}\text { Journal of Optimization } \\
\text { Theory and } \\
\text { Applications }\end{array}$ & 31 & 0.633 & 123 & 12 & United States & 2 \\
\hline $\begin{array}{l}\text { Journal of Quality } \\
\text { Technology }\end{array}$ & 6 & 1.411 & 23 & 4 & United States & 3 \\
\hline Journal of Scheduling & 20 & 0.811 & 29 & 6 & Netherlands & 2 \\
\hline Management Science & 4 & 1.687 & 141 & 12 & United States & 1 \\
\hline $\begin{array}{l}\text { Mathematical Methods of } \\
\text { Operations Research }\end{array}$ & 49 & 0.388 & 65 & 6 & Germany & 2 \\
\hline
\end{tabular}


Appendix. (Continued)

\begin{tabular}{|c|c|c|c|c|c|c|}
\hline Journal Title & $\begin{array}{l}\text { Rank } \\
\text { by IF }\end{array}$ & $\begin{array}{l}\text { Impact } \\
\text { Factor }\end{array}$ & Articles & $\begin{array}{l}\text { Issues/ } \\
\text { Year }\end{array}$ & $\begin{array}{l}\text { Country/ } \\
\text { Territory }\end{array}$ & $\begin{array}{l}\text { Subject } \\
\text { categories }\end{array}$ \\
\hline $\begin{array}{l}\text { Mathematics of } \\
\text { Operations Research }\end{array}$ & 23 & 0.785 & 36 & 4 & United States & 2 \\
\hline $\begin{array}{l}\text { Mathematical } \\
\text { Programming }\end{array}$ & 12 & 1.117 & 91 & 12 & Germany & 3 \\
\hline $\begin{array}{l}\text { Military Operations } \\
\quad \text { Research }\end{array}$ & 60 & 0.08 & 15 & 4 & United States & 1 \\
\hline Naval Research Logistics & 52 & 0.362 & 59 & 8 & United States & 1 \\
\hline $\begin{array}{l}\text { Networks \& Spatial } \\
\text { Economics }\end{array}$ & 43 & 0.486 & 19 & 4 & Netherlands & 2 \\
\hline Networks & 44 & 0.485 & 45 & 7 & United States & 2 \\
\hline $\begin{array}{l}\text { Omega-International } \\
\text { Journal of } \\
\text { Management Science }\end{array}$ & 28 & 0.663 & 52 & 6 & England & 1 \\
\hline Operations Research & 8 & 1.234 & 82 & 6 & United States & 1 \\
\hline $\begin{array}{l}\text { Operations Research } \\
\text { Letters }\end{array}$ & 24 & 0.767 & 94 & 10 & Netherlands & 1 \\
\hline $\begin{array}{l}\text { Optimal Control } \\
\text { Applications } \mathbb{E} \\
\text { Methods }\end{array}$ & 32 & 0.6 & 18 & 6 & England & 3 \\
\hline $\begin{array}{l}\text { Optimization and } \\
\text { Engineering }\end{array}$ & 25 & 0.73 & 25 & 4 & United States & 3 \\
\hline $\begin{array}{l}\text { Optimization Methods } \& 5 \\
\text { Software }\end{array}$ & 38 & 0.563 & 56 & 4 & England & 3 \\
\hline Optimization & 41 & 0.5 & 39 & 6 & England & 2 \\
\hline OR Spectrum & 9 & 1.224 & 32 & 4 & Germany & 1 \\
\hline $\begin{array}{l}\text { Probability in the } \\
\text { Engineering and } \\
\text { Informational Sciences }\end{array}$ & 45 & 0.462 & 39 & 4 & United States & 3 \\
\hline $\begin{array}{l}\text { Production and } \\
\text { Operations } \\
\text { Management }\end{array}$ & 1 & 2.516 & 39 & 4 & United States & 2 \\
\hline $\begin{array}{l}\text { Production Planning } \& 5 \\
\quad \text { Control }\end{array}$ & 48 & 0.438 & 65 & 8 & England & 3 \\
\hline $\begin{array}{l}\text { Quality and Reliability } \\
\text { Engineering } \\
\text { International }\end{array}$ & 40 & 0.508 & 68 & 6 & England & 2 \\
\hline Queueing Systems & 27 & 0.689 & 56 & 12 & Netherlands & 2 \\
\hline $\begin{array}{l}\text { RAIRO-Operations } \\
\quad \text { Research }\end{array}$ & 56 & 0.286 & 16 & 4 & France & 1 \\
\hline $\begin{array}{l}\text { Reliability Engineering } 83 \\
\text { System Safety }\end{array}$ & 15 & 0.92 & 147 & 12 & England & 2 \\
\hline Safety Science & 26 & 0.725 & 57 & 9 & Netherlands & 2 \\
\hline $\begin{array}{l}\text { Systems \& Control } \\
\text { Letters }\end{array}$ & 5 & 1.683 & 125 & 15 & Netherlands & 2 \\
\hline Technovation & 35 & 0.582 & 123 & 12 & Netherlands & 2 \\
\hline $\begin{array}{l}\text { Transportation Research } \\
\quad \text { Part B-Methodological }\end{array}$ & 3 & 1.761 & 52 & 10 & England & 3 \\
\hline $\begin{array}{l}\text { Transportation Research } \\
\text { Part E-Logistics and } \\
\text { Transportation Review }\end{array}$ & 29 & 0.643 & 27 & 6 & England & 3 \\
\hline Transportation Science & 7 & 1.27 & 38 & 4 & United States & 2 \\
\hline
\end{tabular}




\section{References}

Adams, J, R Bajcsy, J Kosecka, V Kumar, M Mintz and R Mandelbaum (1996). Cooperative material handling by human and robotic agents: Module development and system synthesis. Expert Systems with Applications, 11(2), 89-97.

Chan, WL (1975a). Saddle-point characterization of a class of optimal signal detectors. International Journal of Systems Science, 6(12), 1179-1184.

Chan, WL (1975b). Stackelberg strategy for linear quadratic partial-differential games. International Journal of Systems Science, 6(5), 433-441.

Chandrasekharan, MP and R Rajagopalan (1986). An ideal seed non-hierarchical clustering-algorithm for cellular manufacturing. International Journal of Production Research, 24(2), 451-464.

Chandrasekharan, MP and R Rajagopalan (1987). Zodiac: An algorithm for concurrent formation of part-families and machine-cells. International Journal of Production Research, 25(6), 835-850.

Chen, CF and CH Hsiao (1975). State-space approach to Walsh series solution of linearsystems. International Journal of Systems Science, 6(9), 833-858.

Chen, F, Z Drezner, JK Ryan and D Simchi-Levi (2000). Quantifying the bullwhip effect in a simple supply chain: The impact of forecasting, lead times, and information. Management Science, 46(3), 436-443.

Chen, SP and TS Wei (2002). The practice of operational research in Taiwan. Journal of the Operational Research Society, 53(12), 1330-1337.

Erlenkotter, D and AS Manne (1968). Capacity expansion for Indias nitrogenous fertilizer industry. Management Science, 14(10), B553-B572.

Fukushima, M (1992). Equivalent differentiable optimization problems and descent methods for asymmetric variational inequality problems. Mathematical Programming, 53(1), 99-110.

Furuta, K (1990). Sliding mode control of a discrete system. Systems \& Control Letters, 14(2), 145-152.

Garfield, E (1994). The Thomson Scientific impact factor. Current Contents, Retrieved November 15, 2007, from http://scientific.thomson.com/free/essays/ journalcitationreports/impactfactor/

Hirsch, JE (2005). An index to quantify an individual's scientific research output. Proceedings of the National Academy of Sciences of the United States of America, 102(46), 16569-16572.

Keerthi, SS and EG Gilbert (1988). Optimal infinite-horizon feedback laws for a generalclass of constrained discrete-time-systems - stability and moving-horizon approximations. Journal of Optimization Theory and Applications, 57(2), 265-293.

Kirby, MW (2003). Operational Research in War and Peace: The British Experience from the 1930s to 1970. London: Imperial College Press.

Kojima, M, S Mizuno and A Yoshise (1989). A polynomial-time algorithm for a class of linear complementarity-problems. Mathematical Programming, 44(1), 1-26.

Kuby, M, QG Shi, T Watanatada, XF Sun, ZJ Xie and W Cao (1995). Planning China coal and electricity delivery system. Interfaces, 25(1), 41-68.

Langham, MR (1976). Adaptive Economic-Models. Day, RH and T Groves. Interfaces, $7(1), 115-119$.

Lee, SD (1978). Study of differences and characteristics between nations, in measured values of human-body and working area. International Journal of Production Research, 16(4), 335-347.

Lenhard, MS, TRC Johnson, I Himsl, N Ditsch, S Rueckert and K Friese (2006). Obstetrical and gynecological writing and publishing in Europe. European Journal of Obstetrics Gynecology and Reproductive Biology, 129(2), 119-123. 
Miyasawa, K (1968). Information structures in Stochastic programming problems. Management Science, 14(5), 275-291.

Pardoux, E and SG Peng (1990). Adapted solution of a backward stochastic differentialequation. Systems \& Control Letters, 14(1), 55-61.

Pearn, WL, S Kotz and NL Johnson (1992). Distributional and inferential properties of process capability indexes. Journal of Quality Technology, 24(4), 216-231.

Ranyard, JC (1995). Supporting real decisions: A review of OR practice in the UK. European Journal of Operational Research, 87(3), 474-482.

Senju, S and Y Toyoda (1968). Approach to linear programming with 0-1 variables. Management Science, 15(4), B196-B207.

Shih, YP and CK Chu (1975). Optimal feedback-control of a class of linear distributed systems. Journal of Optimization Theory and Applications, 16(3-4), 327-338.

Sugimori, Y, K Kusunoki, F Cho and S Uchikawa (1977). Toyota production system and Kanban system materialization of just-in-time and respect-for-human system. International Journal of Production Research, 15(6), 553-564.

Tam, KY and MY Kiang (1992). Managerial applications of neural networks - The case of bank failure predictions. Management Science, 38(7), 926-947.

Wu, WT and YP Shih (1975). Approximation of irrational transfer-function exp(-squareroot $s$ ) by Ritz method. International Journal of Systems Science, 6(2), 175-180.

Zheng, YP (1981), Some basic algebraic relations in the order-reduction of large-scale systems by aggregation. Optimal Control Applications 83 Methods, 2(1), 75-79.

Pao-Long Chang is a chair professor at the Department of Business Administration, Feng Chia University, Taichung, Taiwan. He received a BS in Mathematics from Fu-Jen Catholic University in Taiwan, an MA in Mathematics from the State University of New York at Albany, and a PhD in Mathematics from the University of Washington in the USA.

His previous articles have appeared in the Journal of the Operational Research Society, Journal of Environmental Management, Computers and Operations Research, Industry and Innovation, International Journal of Production Research, International Journal of Technology Management, Technovation, IEEE Transactions on Engineering Management, and Journal of Engineering and Technology Management, among others.

His current research interests are in the areas of technology management and operations research.

Pao-Nuan Hsieh is an associate professor in the Department of Library and Information Science, National Taiwan University, Taipei, Taiwan. She received her bachelor's and master's degrees from the Department of Library Science at National Taiwan University, Taipei, Taiwan, in 1985 and 1989, respectively; and a PhD degree from the Institute of Business and Management, National Chiao-Tung University, Taipei, Taiwan.

Her primary research interests are in the areas of bibliometric analysis, citation analysis, and information architecture. She has published her research in journals such as Libri, Library Review, Journal of Library Science, and Higher Education. 